\title{
To Compare the Effect of Weather on Growth, Development and Yield of Chickpea under Irrigated and Unirrigated Conditions
}

\author{
Yamlesh Nishad", A.S.R.A.S. Sastri and Usha Durgam \\ Department of Agrometeorology, Indira Gandhi Krishi Vishwavidyalaya, \\ Raipur-492012 (C.G), India \\ *Corresponding author
}

\section{A B S T R A C T}

The present investigation entitled "To compare the effect of weather on growth, development and yield of chickpea under irrigated and unirrigated conditions" was conducted during rabi season 2013-14 at Research Farm of Indira Gandhi Krishi Vishwavidyalaya, Raipur (Chhattisgarh). Studies were carried out on different

\section{Keywords}

Growth, Development, Yield of chickpea, Weather, Temperature

Article Info

Accepted:

12 October 2018

Available Online:

10 November 2018 phenological stages right from sowing to harvesting under irrigated and unirrigated conditions in the three dates of sowing. Based on the duration of different phenological stages the average maximum and minimum temperatures at different growth stages in the different dates of sowing were workout. For comparative analysis Stevenson screen was installed in the crop field and the average maximum and minimum temperatures at different growth stages were also workout using the field data. The duration for sowing to germination, Grand growth, Bud formation, first flowering, $50 \%$ flowering, pod development and physiological maturity for three different dates of sowings under irrigated and un irrigated condition was recorded and analyzed. It was found that from first flowering to $50 \%$ flowering onwards the duration under different dates of sowing in unirrigated condition is less when compared to irrigated condition. The average maximum temperature under $\mathrm{D}_{1}$ in the germination to grand growth stage is higher in the first date of sowing. However, later on that is from grand growth to bud formation the maximum temperature is higher in $\mathrm{D}_{1}$ as compare to $\mathrm{D}_{2}$ and $\mathrm{D}_{3}$ both in field as well as observatory data.

\section{Introduction}

Climate and weather conditions which influence human activities and environmental resources sustainability include; rainfall, temperature (minimum, average, maximum), pressure, humidity, solar radiation, visibility, evaporation, soil temperature at various depths, wind speed and direction among others. The climate is the least manageable part of environmental resources, yet a better understanding of the climatic resources and their interaction with crops can help to increase the crop productivity.

Plant development depends on temperature and requires a specific amount of heat to develop from one point in their lifecycle to another, such as from seeding to the harvest stage. Temperature is a key factor for the 
timing of biological processes and hence regulates the growth and development of plants. Crop heat unit (CHU) or thermal time or growing degree days is a temperature response of development that differs between day and night. Growing degree days is a way of assigning a heat value to each day. Heat units are involved in several physiological processes like specific amount of heat units required for the plant at each stage from its germination to harvest of the crop and they would vary. The important processes are growth and development, growth parameters, metabolism, biomass, physiological maturity and yield. Growing degree days are used to assess the suitability of a region for production of a particular crop, determine the growth stages of crops, assess the best timing of fertilizer, herbicide and plant growth regulators application, estimate heat stress accumulation on crops, predict physiological maturity and harvest dates and ideal weather unit in constructing crop weather models (Parthasarathi et al., 2013).

The chickpea grain yield is related to its phenology which is influenced by temperature. The timing and duration of flowering has an important role in determining crop duration and grain yield at high temperature. The crop is forced into maturity under hot and dry condition $\left(>30^{\circ} \mathrm{C}\right)$ by reducing the crop duration (Summerfield et al., 1984).

\section{Materials and Methods}

The present study entitled "Studies on the effect of weather and irrigation on growth, development and yields of chickpea under Raipur conditions." was conducted during the rabi season of 2013-14. The details of experimental soil, prevailing weather conditions, materials used and techniques adopted during the course of the investigation are briefly presented in this chapter.

\section{Location of experimental site}

The field experiment was conducted at the research farm, Indira Gandhi Krishi Vishwavidyalaya; Raipur situated in South Eastern Central part of Chhattisgarh at latitude, longitude and altitude of $21^{\circ} 16^{\prime}, \mathrm{N}$, longitude $81^{\circ} 36^{\prime \prime} \mathrm{E}$ and $289.5 \mathrm{~m}$ above mean sea level respectively.

\section{Climate}

The climate of Chhattisgarh state is dry sub humid. Nearly $90 \%$ of the annual average rainfall occurs from June to September during south west monsoon.

During the growth period the maximum temperature ranged between $22^{\circ} \mathrm{C}$ to $36.3^{\circ} \mathrm{C}$ while minimum temperature ranged between 8 and $20.7^{0} \mathrm{C}$.

The morning relative humidity varied from 59 to $100 \%$ whereas. The afternoon humidity varied from 20 to $83 \%$ (47 SMW and 12 SMW).

\section{Experimental detail}

The details of the treatments are given below and experimental lay out is shown in Figure 1. The cropping history of the experimental field is furnished in Table 1.

\section{Soil}

The soil of the experimental site is clay loam in texture of (Alfisol group) locally known as "Dorsa" The soil was neutral in reaction and had low phosphorous medium nitrogen and potassium content.

\section{Variety}

JG-130: This cultivar is suitable for rainfed as well as irrigated conditions. 


\section{Field preparation}

The field was ploughed twice with tractor and weeds were removed. Then it was leveled with the help of tractor driven leveler.

\section{Fertilizer application}

Fertilizer was applied to the crop as per recommended dose of nitrogen, phosphorus and potash i.e., 20:40:20 (N: P: K) Kg/ha full dose of $\mathrm{N}$ : P: K was applied as basal dose before sowing in rows.

\section{Seed rate and sowing}

After field preparation, the sowing was done in line at a distance of $10 \times 10 \mathrm{~cm}$ plant to plant and $30 \times 30 \mathrm{~cm}$ row to row distance. The sowing was done with a seed rate of $80 \mathrm{~kg}$ /ha.

\section{Harvesting}

The crop was harvested manually on different dates with the help of sickle from 11 March to 03 April when the crop attained full maturity. Two rows from the either side of each plot and $50 \mathrm{~cm}$ from other two ends were harvested separately and removed as border.

The produce of each net plot was tied into bundle and allowed to sun drying in respective plots.

The harvested bundles were weighted with the help of spring balance and transported to threshing floor.

\section{Irrigation}

Only one irrigation (Excluding pre sowing irrigation) was given to the crop under irrigation treatment. Under irrigated condition first irrigation was given at 45 days after sowing.

\section{Harvesting and threshing}

Harvesting was done for different dates of sowing under irrigated and unirrigated conditions as per maturity of the crop. The data were recorded in the 10 selected plot of 1 $\mathrm{m}^{2}$ area.

Threshing was done after two days sun drying and then grain were cleaned and weighted for each plot in each treatment.

\section{Results and Discussion}

The present investigation was carried with three different environments for the chickpea crop to study the effect of weather on crop growth and development and yield of chickpea.

Weather data was collected both from crop field and nearby weather station right from first date of sowing to harvesting. The daily weather data collected from crop field and experimental field

\section{Weather condition during crop growth period}

For analysis of data, weekly averages based on standard meteorological weeks were worked out for both observatory and field and they are shown in Table 2 and 3. When the data are compared it was found that in the initial weeks the field data and observatory data were the same in respect of dry bulb temperature both in morning and evening hours. Later from third week onwards the dry bulb temperature in the field was lower by 0.2 to $0.4{ }^{\circ} \mathrm{C}$. However, when the maximum temperature was examined it was found that the maximum temperature in the observatory is higher than the field observatory by 0.2 to $0.6^{\circ} \mathrm{C}$ throughout the growing season. Similarly the minimum temperature was also higher in the observatory when compared to field data. 


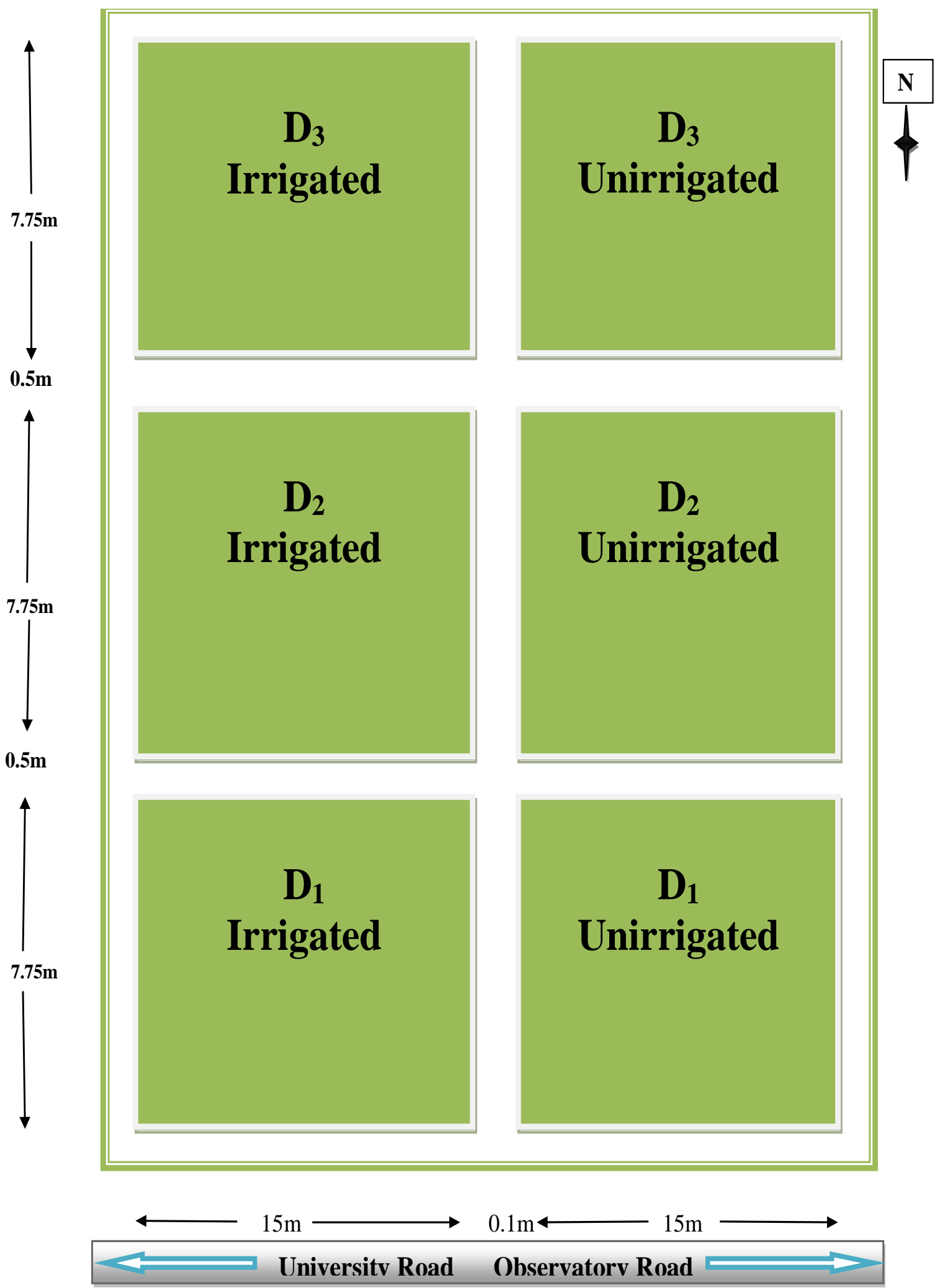

Fig.1 Layout plan of experimental chickpea field 

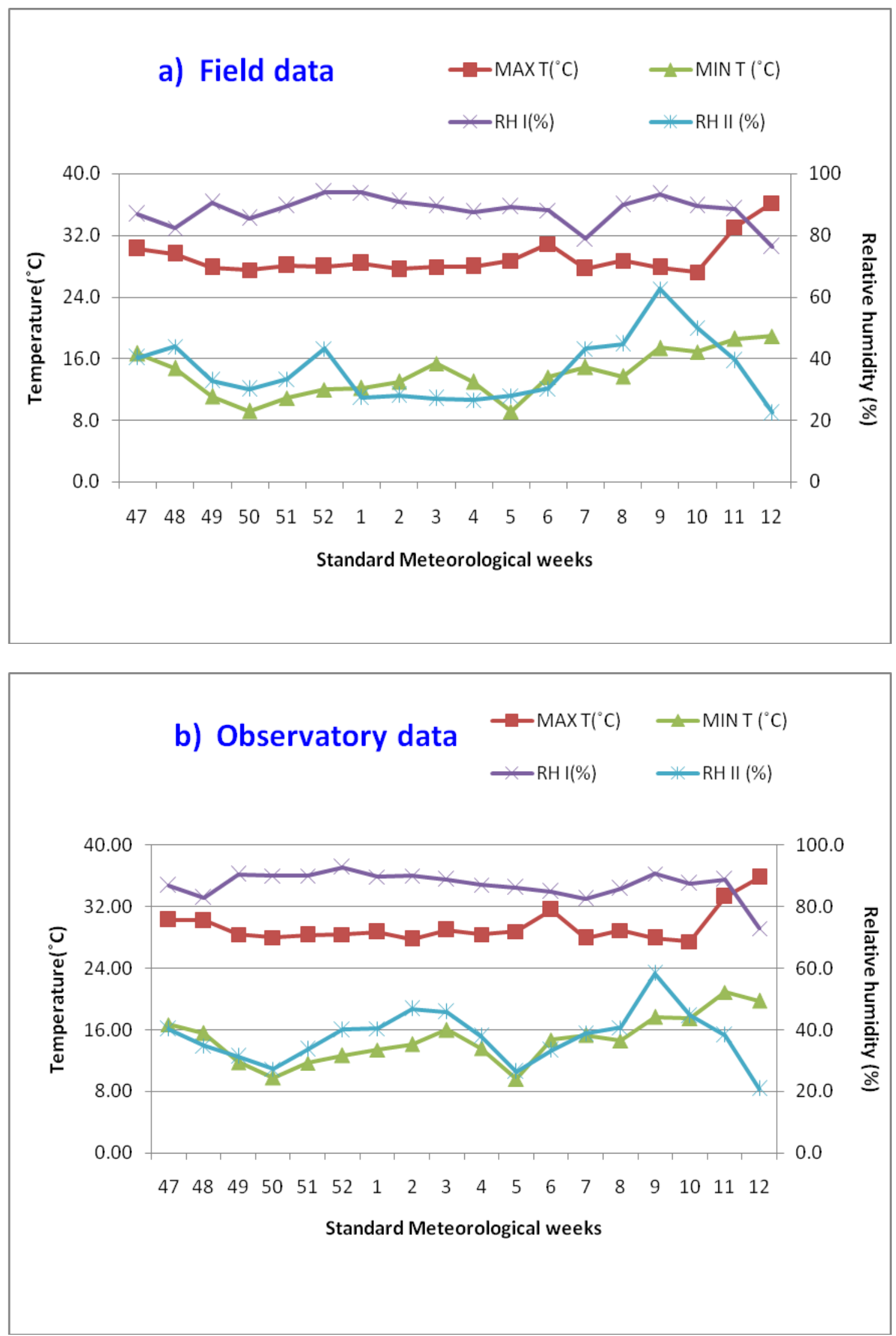


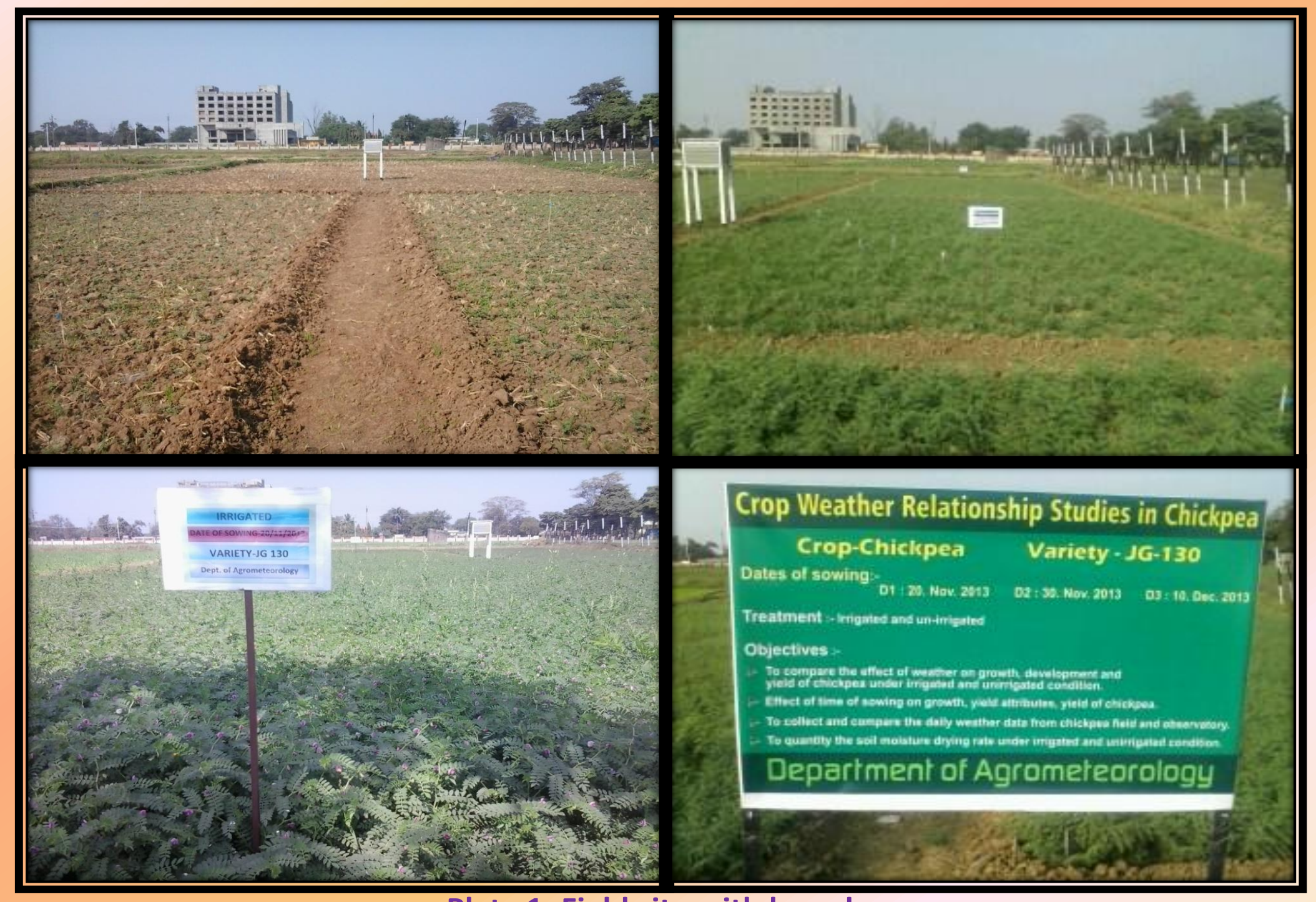

Plate 1: Field site with board 


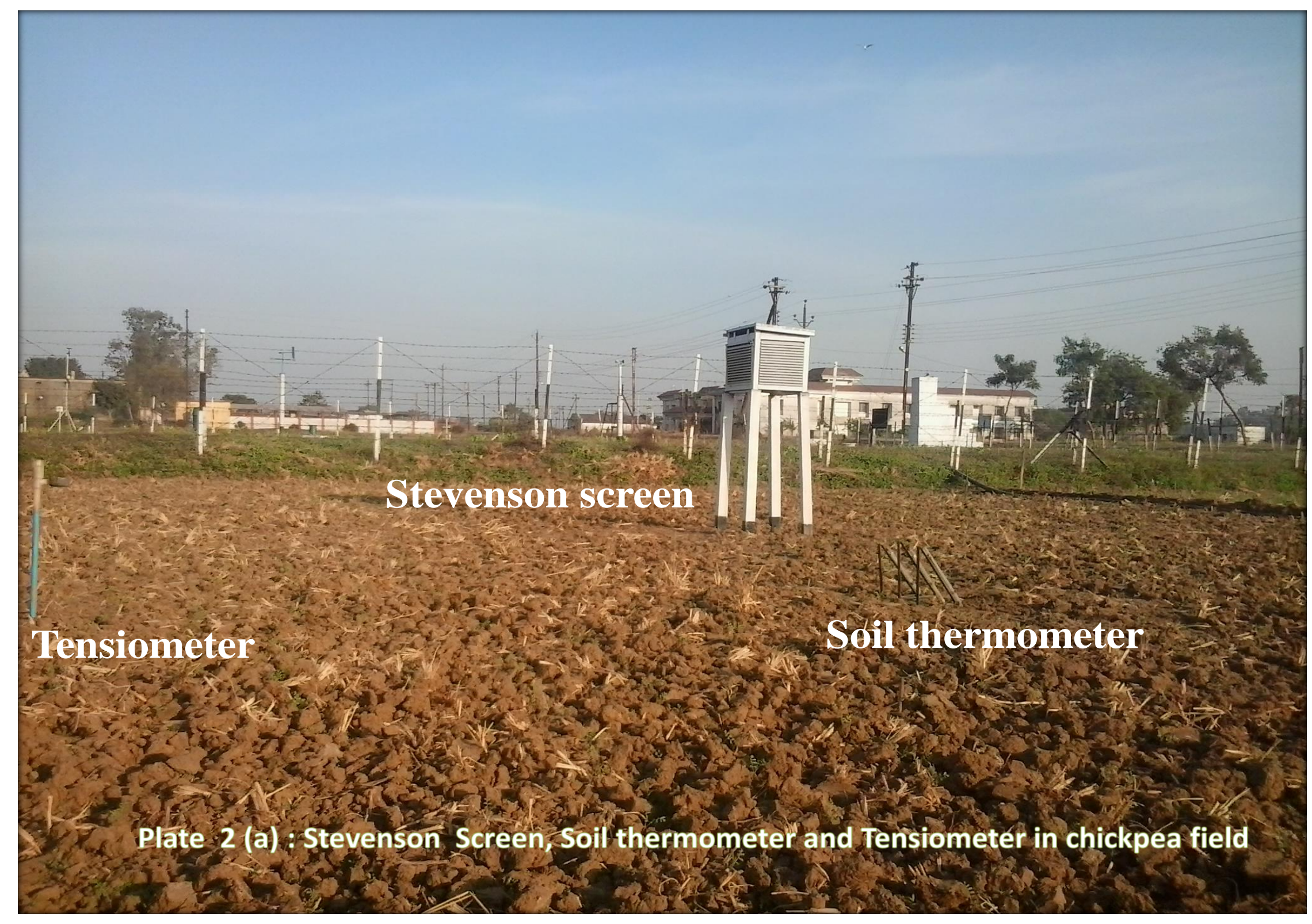




\section{Experimental Detail}

\begin{tabular}{|c|c|}
\hline Season & : Rabi-2013-14 \\
\hline Crop & : chickpea (cicer arietinum) \\
\hline Variety & : JG-130 \\
\hline \multirow[t]{4}{*}{ Dates of Sowing } & : Three \\
\hline & : $\mathrm{D}_{1}-20$ Nov. 2013 \\
\hline & $: \mathrm{D}_{2}-30$ Nov 2013 \\
\hline & : $\mathrm{D}_{3}-10$ Dec. 2013 \\
\hline Soil & : Clay loam \\
\hline Seed rate & : $80 \mathrm{~kg} / \mathrm{ha}$ \\
\hline Fertilizer doses & : 20:40:20 kg/ha. $\mathrm{N}: \mathrm{P}_{2} \mathrm{O}_{5}: \mathrm{K}_{2} \mathrm{O}$ \\
\hline Spacing & $: 30 \mathrm{~cm} \mathrm{X} 10 \mathrm{~cm}$ \\
\hline Total number of plots & $: 6$ \\
\hline Total plot area & $: 120 \mathrm{~m}^{2}$ \\
\hline Total experimental area & $: 782.0 \mathrm{~m}^{2}$ \\
\hline Plot to plot distance & $: 0.5 \mathrm{~m}$ \\
\hline Statistical analysis & : 't' test \\
\hline
\end{tabular}

Table.1 Cropping history of the experimental field

\begin{tabular}{|c|c|c|}
\hline \multirow{2}{*}{ Year } & \multicolumn{2}{|c|}{ Crop } \\
\hline & Kharif & Rabi \\
\hline $2011-12$ & Rice & Wheat \\
\hline $2012-13$ & Rice & Wheat \\
\hline $2013-14$ & Rice & Chickpea \\
\hline
\end{tabular}


Table.2 March of weekly meteorological parameters recorded in the experimental field during rabi season 2013-14 at Labhandi, Raipur

\begin{tabular}{|c|c|c|c|c|c|c|c|c|c|}
\hline Week No. & Date & $\begin{array}{c}\text { Dry bulb } \\
\text { temperature } \\
\left({ }^{0} \mathrm{C}\right) \text { I }\end{array}$ & $\begin{array}{c}\text { Wet bulb } \\
\text { temperature } \\
\left({ }^{0} \mathrm{C}\right) \text { I }\end{array}$ & $\begin{array}{c}\text { Dry bulb } \\
\text { temperature } \\
\left({ }^{0} \mathrm{C}\right) \text { II }\end{array}$ & $\begin{array}{c}\text { Wet bulb } \\
\text { temperature } \\
\left({ }^{0} \mathrm{C}\right) \\
\text { II }\end{array}$ & $\begin{array}{c}\text { Maximum } \\
\text { Temperature } \\
\left({ }^{0} \mathrm{C}\right)\end{array}$ & $\begin{array}{c}\text { Minimum } \\
\text { temperature } \\
\left({ }^{0} \mathrm{C}\right)\end{array}$ & $\begin{array}{c}\text { Relative } \\
\text { humidity } \\
(\%) \\
\text { I }\end{array}$ & $\begin{array}{c}\text { Relative } \\
\text { humidity } \\
(\%) \\
\text { II }\end{array}$ \\
\hline 47 & November $19-25$ & 17.7 & 16.5 & 29.4 & 20.3 & 30.3 & 16.7 & 87.0 & 40.3 \\
\hline 48 & $26-02$ & 16.9 & 15.2 & 28.8 & 20.4 & 29.6 & 14.8 & 82.4 & 43.9 \\
\hline 49 & December 03-09 & 12.7 & 12.0 & 26.7 & 17.0 & 27.8 & 11.1 & 90.7 & 32.9 \\
\hline 50 & 10-16 & 10.9 & 10.0 & 26.4 & 16.3 & 27.5 & 9.2 & 85.6 & 30.1 \\
\hline 51 & $17-23$ & 12.6 & 11.7 & 27.2 & 17.5 & 28.1 & 10.9 & 89.7 & 33.4 \\
\hline 52 & $24-31$ & 13.2 & 12.6 & 26.8 & 18.7 & 28.0 & 12.0 & 94.0 & 43.3 \\
\hline 1 & January 01-07 & 13.9 & 13.3 & 27.0 & 18.6 & 28.4 & 12.2 & 93.9 & 27.4 \\
\hline 2 & 08-14 & 14.2 & 13.4 & 27.7 & 19.9 & 27.6 & 13.0 & 91.0 & 28.0 \\
\hline 3 & $15-21$ & 16.6 & 15.7 & 26.7 & 19.4 & 27.9 & 15.4 & 89.6 & 27.0 \\
\hline 4 & $22-28$ & 14.3 & 13.3 & 26.3 & 17.4 & 28.0 & 13.0 & 87.7 & 26.6 \\
\hline 5 & $29-04$ & 10.3 & 9.5 & 28.0 & 17.9 & 28.7 & 9.1 & 89.4 & 27.9 \\
\hline 6 & February 05-11 & 14.9 & 13.9 & 30.0 & 20.1 & 30.9 & 13.6 & 88.1 & 30.3 \\
\hline 7 & $12-18$ & 16.4 & 14.4 & 25.8 & 17.7 & 27.7 & 14.9 & 79.0 & 43.3 \\
\hline 8 & $19-25$ & 15.2 & 14.2 & 28.6 & 21.2 & 28.7 & 13.7 & 90.0 & 44.7 \\
\hline 9 & $26-04$ & 18.3 & 17.6 & 26.0 & 20.1 & 27.8 & 17.4 & 93.4 & 62.6 \\
\hline 10 & March 05-11 & 18.7 & 17.7 & 27.7 & 20.4 & 27.2 & 16.9 & 89.6 & 50.1 \\
\hline 11 & $12-18$ & 20.7 & 19.6 & 33.1 & 22.6 & 33.1 & 18.6 & 88.7 & 39.4 \\
\hline 12 & $19-25$ & 21.5 & 18.9 & 35.9 & 20.9 & 36.2 & 18.9 & 76.4 & 22.4 \\
\hline
\end{tabular}


Table.3 March of weekly meteorological parameters recorded at agromet observatory during rabi season 2013-14 at Labhandi, Raipur

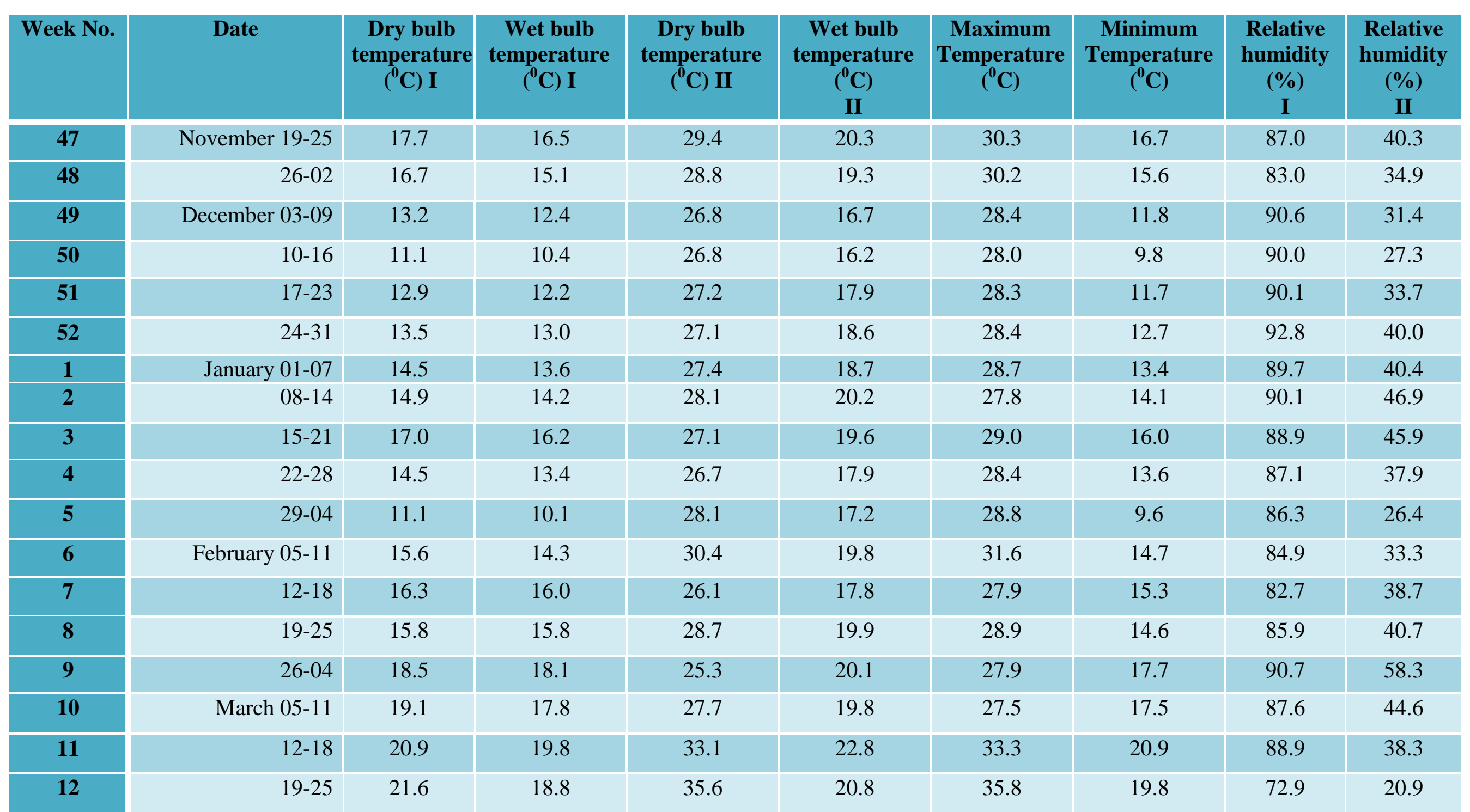


Table.4 Phenological observations in chickpea crop for three different dates of sowing under irrigated and unirrigated conditions

\begin{tabular}{|c|c|c|c|c|c|c|}
\hline \multirow{5}{*}{$\begin{array}{l}\text { S. } \\
\mathbf{N} \\
\mathbf{1}\end{array}$} & \multirow{5}{*}{$\begin{array}{c}\text { Particular } \\
\text { Dates of sowing }\end{array}$} & \multirow{2}{*}{\multicolumn{2}{|c|}{ DAS }} & \multicolumn{3}{|c|}{ Dates of observations } \\
\hline & & & & \multirow{2}{*}{$\begin{array}{c}\text { Irrigated } \\
\text { 20/11/2013 }\end{array}$} & \multicolumn{2}{|c|}{ Unirrigated } \\
\hline & & $\mathbf{D}_{1}$ & $\mathbf{0}$ & & $\mathbf{0}$ & $20 / 11 / 2013$ \\
\hline & & $\mathbf{D}_{2}$ & $\mathbf{0}$ & $30 / 11 / 2013$ & $\mathbf{0}$ & $30 / 11 / 2013$ \\
\hline & & $\mathbf{D}_{3}$ & $\mathbf{0}$ & $10 / 12 / 2013$ & $\mathbf{0}$ & $10 / 12 / 2013$ \\
\hline \multirow[t]{3}{*}{2} & \multirow[t]{3}{*}{ Dates of Germination } & $\mathbf{D}_{1}$ & 5 & $25 / 11 / 2013$ & 5 & $25 / 11 / 2013$ \\
\hline & & $\mathbf{D}_{2}$ & 7 & $07 / 12 / 2013$ & 7 & $07 / 12 / 2013$ \\
\hline & & $\mathbf{D}_{3}$ & 9 & $19 / 12 / 2013$ & 9 & $19 / 12 / 2013$ \\
\hline \multirow[t]{3}{*}{3} & \multirow[t]{3}{*}{ Dates of Grand growth } & $\mathbf{D}_{1}$ & 18 & $08 / 12 / 2013$ & 18 & $08 / 12 / 2013$ \\
\hline & & $\mathbf{D}_{2}$ & 23 & $23 / 12 / 2013$ & 22 & $2212 / 2013$ \\
\hline & & $\mathbf{D}_{3}$ & 31 & $10 / 01 / 2014$ & 31 & $10 / 01 / 2014$ \\
\hline \multirow[t]{3}{*}{4} & \multirow[t]{3}{*}{ Dates of Bud formation } & $\mathbf{D}_{1}$ & 44 & $03 / 01 / 2014$ & 44 & $03 / 01 / 2014$ \\
\hline & & $\mathbf{D}_{2}$ & 46 & $15 / 01 / 2014$ & 47 & $16 / 01 / 2014$ \\
\hline & & $\mathbf{D}_{3}$ & 41 & $20 / 01 / 2014$ & 41 & $20 / 01 / 2014$ \\
\hline \multirow[t]{3}{*}{5} & \multirow[t]{3}{*}{ Dates of First flowering } & $\mathbf{D}_{1}$ & 45 & 04/01/2014 & 46 & $05 / 01 / 2014$ \\
\hline & & $\mathbf{D}_{2}$ & 48 & $17 / 01 / 2014$ & 48 & $17 / 01 / 2014$ \\
\hline & & $\mathbf{D}_{3}$ & 44 & $23 / 01 / 2014$ & 43 & $22 / 01 / 2014$ \\
\hline \multirow[t]{3}{*}{6} & \multirow[t]{3}{*}{ Dates of $50 \%$ flowering } & $\mathbf{D}_{1}$ & 59 & 19/01/2014 & 55 & $14 / 01 / 2014$ \\
\hline & & $\mathbf{D}_{2}$ & 58 & 27/01/2014 & 53 & $22 / 01 / 2014$ \\
\hline & & $\mathbf{D}_{3}$ & 55 & $02 / 02 / 2014$ & 47 & $26 / 01 / 2014$ \\
\hline \multirow[t]{3}{*}{7} & \multirow[t]{3}{*}{$\begin{array}{l}\text { Dates of Pod } \\
\text { development }\end{array}$} & $\mathbf{D}_{1}$ & 69 & 28/01/2014 & 69 & $18 / 01 / 2014$ \\
\hline & & $\mathbf{D}_{2}$ & 65 & $03 / 02 / 2014$ & 60 & $29 / 01 / 2014$ \\
\hline & & $\mathbf{D}_{3}$ & 59 & 07/02/2014 & 54 & $02 / 02 / 2014$ \\
\hline \multirow[t]{3}{*}{8} & \multirow[t]{3}{*}{ Harvest } & $\mathbf{D}_{1}$ & 107 & 07/03/2014 & 98 & $21 / 02 / 2014$ \\
\hline & & $\mathbf{D}_{2}$ & 105 & $15 / 03 / 2014$ & 98 & $08 / 03 / 2014$ \\
\hline & & $\mathbf{D}_{3}$ & 103 & $23 / 03 / 2014$ & 84 & $04 / 03 / 2014$ \\
\hline
\end{tabular}


Table.5 Mean maximum temperature at different phenological stages based on observatory and field data in the Three different dates of sowing

\begin{tabular}{|c|c|c|c|c|c|c|c|}
\hline \multirow{2}{*}{$\begin{array}{l}\text { Dates of } \\
\text { sowing }\end{array}$} & \multicolumn{7}{|c|}{ Phenological stages } \\
\hline & $\begin{array}{l}\text { Sowing to } \\
\text { germination }\end{array}$ & $\begin{array}{c}\text { Germination } \\
\text { to grand } \\
\text { growth }\end{array}$ & $\begin{array}{c}\text { Grand growth } \\
\text { to bud } \\
\text { formation }\end{array}$ & $\begin{array}{c}\text { Bud formation } \\
\text { to first } \\
\text { flowering }\end{array}$ & $\begin{array}{c}\text { First } \\
\text { flowering to } \\
50 \% \\
\text { flowering }\end{array}$ & $\begin{array}{l}50 \% \text { flowering } \\
\text { to pod } \\
\text { development }\end{array}$ & $\begin{array}{c}\text { Pod } \\
\text { development to } \\
\text { physiological } \\
\text { maturity }\end{array}$ \\
\hline $\begin{array}{c}\mathrm{D}_{1} \\
\text { Observatory }\end{array}$ & 37.8 & 29.8 & 28.2 & 28.5 & 28.6 & 28.2 & 28.0 \\
\hline $\mathrm{D}_{1}$ Field & 37.8 & 29.1 & 27.9 & 28.5 & 28.0 & 28.0 & 27.8 \\
\hline $\begin{array}{c}\mathrm{D}_{2} \\
\text { observatory }\end{array}$ & 34.8 & 27.9 & 28.3 & 29.5 & 28.6 & 28.4 & 29.2 \\
\hline $\mathrm{D}_{2}$ Field & 34.1 & 27.6 & 28.0 & 29.4 & 27.7 & 28.1 & 28.9 \\
\hline $\begin{array}{c}D_{3} \\
\text { observatory }\end{array}$ & 31.6 & 28.4 & 28.5 & 29.0 & 28.1 & 30.2 & 30.2 \\
\hline$D_{3}$ Field & 31.1 & 28.1 & 27.8 & 28.7 & 27.8 & 29.8 & 29.9 \\
\hline
\end{tabular}


Table.6 Mean minimum temperatures at different phenological stages based on observatory and field data in Three different dates of sowing

\begin{tabular}{|c|c|c|c|c|c|c|c|}
\hline \multirow{2}{*}{ Dates of sowing } & \multicolumn{7}{|c|}{ Phenological stages } \\
\hline & $\begin{array}{l}\text { Sowing to } \\
\text { germination }\end{array}$ & $\begin{array}{l}\text { Germination to } \\
\text { grand growth }\end{array}$ & $\begin{array}{c}\text { Grand growth } \\
\text { to bud } \\
\text { formation }\end{array}$ & $\begin{array}{c}\text { Bud formation } \\
\text { to first } \\
\text { flowering }\end{array}$ & $\begin{array}{c}\text { First } \\
\text { flowering to } \\
50 \% \\
\text { flowering }\end{array}$ & $\begin{array}{l}50 \% \text { flowering } \\
\text { to pod } \\
\text { development }\end{array}$ & $\begin{array}{c}\text { Pod } \\
\text { development to } \\
\text { physiological } \\
\text { maturity }\end{array}$ \\
\hline $\mathrm{D}_{1}$ Observatory & 21.6 & 14.6 & 11.5 & 12.9 & 14.6 & 14.8 & 13.9 \\
\hline $\mathrm{D}_{1}$ Field & 21.0 & 14.0 & 10.8 & 12.0 & 13.5 & 14.2 & 13.4 \\
\hline $\mathrm{D}_{2}$ observatory & 17.3 & 24.1 & 13.3 & 15.3 & 15.4 & 9.9 & 16.2 \\
\hline $\mathrm{D}_{2}$ Field & 16.5 & 9.8 & 12.4 & 14.6 & 14.8 & 9.4 & 15.3 \\
\hline$D_{3}$ observatory & 11.2 & 12.8 & 15.5 & 14.7 & 12.0 & 10.7 & 17.2 \\
\hline $\mathbf{D}_{3}$ Field & 10.5 & 11.9 & 14.6 & 14.1 & 11.4 & 10.3 & 16.3 \\
\hline
\end{tabular}


The relative humidity both in morning and afternoon hours was higher in the chickpea field, when compared to observatory. The march of maximum and minimum temperatures and relative humidity in the field as well as observatory are shown in Figure 2. It is observed from the figure that the range of temperature as well as relative humidity is higher during the crop growing season. This higher range of temperature is responsible for the lower productivity of chickpea in this region.

\section{Average temperature conditions on} different dates of sowing

\section{Maximum temperature}

Based on phenological observations the average maximum temperature and minimum temperature during different growth stages in different dates of sowing are shown in Table 5. The average maximum temperature under $\mathrm{D}_{1}$ in the germination to grand growth stage is higher in the first date of sowing. However, later on that is from grand growth to bud formation the maximum temperature is higher in $D_{3}$ as compare to $D_{2}$ and $D_{1}$ both in field as well as observatory. The average maximum temperature varied from $37.8{ }^{\circ} \mathrm{C}$ to $28.0^{\circ} \mathrm{C}$ under first date of sowing. In the second date of sowing the maximum temperature varied from 34.8 to $29.2^{0} \mathrm{C}$, in the observatory data. In the field data it varied from 37.8 to $27.8^{\circ} \mathrm{C}$ in first date of sowing and from 34.1 to $28.9^{\circ} \mathrm{C}$ in the second date of sowing. In the third date of sowing the maximum temperature varied from 31.6 to $28.1^{\circ} \mathrm{C}$ in observatory data while in the field data it varied from 31.1 to $27.8^{0} \mathrm{C}$.

\section{Minimum temperature}

The minimum temperature at different growth stages based on both field and observatory data is shown in table 6 . The minimum temperature in the first date of sowing varied from $21.6^{\circ} \mathrm{C}$ to $11.5{ }^{0} \mathrm{C}$ under different phenologial stages based on observatory data.

While in the field data it varied from $21.0^{\circ} \mathrm{C}$ to $10.8^{0} \mathrm{C}$ during different growth stages. In the second date of sowing the minimum temperature based on observatory data varied from $24.1^{\circ} \mathrm{C}$ to $9.9^{0} \mathrm{C}$ while, in the field data it varied from $16.5^{\circ} \mathrm{C}$ to $9.4^{\circ} \mathrm{C}$ in different growth stages. In the third date of sowing the minimum temperature varied from $10.7^{\circ} \mathrm{C}$ to $17.2^{0} \mathrm{C}$ in different growth stages based on the observatory data, while based on the field data the minimum temperature varied from $10.3^{0} \mathrm{C}$ to $16.3^{0} \mathrm{C}$ in different growth stages.

\section{References}

Agegnehu, G. and Sinebo, W. (2012). Drainage, sowing date and variety effects on chickpea grown on a Vertisol in Ethiopia. Arch. Agro. and Soil Sci. 58(1): 101-113.

Agrwal, K. K. and Uadhyay, A. P. (2009) Thermal indices for suitable sowing time of chickpea in Jabalpur Region of Madhya Pradesh. J. Agromet. 11 (1): 89-91

Ahmed, A. G., Zaki, N. M., Magda, H., Mohamed M. M., Tawfik and Hassanein, M. S. (2013). Growth and Yield Response of Two Chickpea Cultivars (Cicer arietinum L.) to Skipping One Irrigation. Middle East J. Agri. Res. 2(4): 146-151.

Badani, H., Katzir, I. and Gera, G. (2010) Influence of Sowing Date on Yields of Fresh-harvested Chickpea. J. Agri. Sci. 2(4):83-88.

Chand, M., Singh, D., Roy, N., Kumar, V. and Singh, R. B. (2010). Effect of growing degree days on chickpea production in Bundelkhand region of Uttar Pradesh. J. Food Legumes 23(1): 41-43. 
Davis, S., Turner, N.C., Siddique, K.H.M., Leport, L. and Plummer, J. (1999). Seed growth of Desi and Kabuli chickpea (Cicer arietinum L.) in a short season Mediterranean-type environment. Aust. J. Exp. Agric. 39:181-188.

Parthasarathi, T., Velu, G., and Jeyakumar, P. (2013). Impact of Crop Heat Units on Growth and Developmental Physiology of Future Crop Production: A Review. Research \& Reviews: A J. Cro. Sci. Tech. 2(1): 2319-3395.
Patel, K. B., Tandel, Y. N. and Arvadia, M. K. (2009). Yield and water use of chickpea (Cicer arietinum L.) as influenced by irrigation and land configuration. Int. J. Agri. Sci.: 369370.

Rao, D. L. N., Giller, K. E., Yeo, A.R. and Flowers, T. J. (2002). The effects of salinity and sod city upon nodulation and nitrogen fixation in chickpea (Cicer arietinum L.). Ann. Bot. 89 (5):563-570.

\section{How to cite this article:}

Yamlesh Nishad, A.S.R.A.S. Sastri and Usha Durgam. 2018. To Compare the Effect of Weather on Growth, Development and Yield of Chickpea under Irrigated and Unirrigated Conditions. Int.J.Curr.Microbiol.App.Sci. 7(11): 1744-1758.

doi: https://doi.org/10.20546/ijcmas.2018.711.200 